\title{
Pemodelan Faktor-faktor yang Mempengaruhi Tingkat Pengangguran Terbuka di Provinsi Jawa Timur Tahun 2015 Menggunakan Regresi Spasial
}

\author{
Ida Puspita Ningtias dan Santi Puteri Rahayu \\ Departemen Statistika, Fakultas MIPA, Institut Teknologi Sepuluh Nopember (ITS) \\ e-mail: santi_pr@statistika.its.ac.id
}

\begin{abstract}
Abstrak-Pada penelitian ini, regresi spasial digunakan untuk mengetahui faktor-faktor yang mempengaruhi tingkat pengangguran terbuka di Provinsi Jawa Timur tahun 2015. Aspek spasial diduga sebagai salah satu faktor yang berpengaruh terhadap tingkat pengangguran terbuka. Pengangguran terbuka terjadi karena jumlah penduduk meningkat sehingga menyebabkan jumlah angkatan kerja meningkat namun jumlah penduduk yang bekerja tidak meningkat. Penelitian ini bertujuan untuk menggambarkan karakteristik faktor-faktor yang diduga mempengaruhi tingkat pengangguran terbuka di Provinsi Jawa Timur kemudian dilanjutkan dengan pemodelan menggunakan regresi spasial. Data yang digunakan bersumber dari website Badan Pusat Statistik (BPS) Provinsi Jawa Timur serta publikasi Keadaan Angkatan Kerja di Jawa Timur Agustus 2015. Berdasarkan hasil analisis dan pembahasan, tingkat pengangguran terbuka pada kabupaten dan kota terhadap kategori tinggi memusat di Provinsi Jawa Timur sebelah timur laut sedangkan untuk kategori sedang dan rendah tersebar di seluruh kabupaten dan kota di Provinsi Jawa Timur. Hasil pemodelan regresi spasial diperoleh spatial error model menggunakan bobot rook contiguity merupakan model terbaik sebab memiliki nilai AIC paling rendah diantara multiple linier regression dan spatial autoregressive model. Variabel yang signifikan berpengaruh terhadap spatial error model adalah persentase penduduk miskin serta distribusi PDRB atas dasar harga berlaku menurut lapangan usaha jasa lainnya. Kabupaten Gresik dan Kabupaten Sidoarjo merupakan dua kabupaten yang paling mempengaruhi spatial error model Kota Surabaya dimana kota ini sebagai ibukota Provinsi Jawa Timur.
\end{abstract}

Kata Kunci-Dependensi Spasial, Multiple Linier Regression, Spatial Autoregressive Model, Spatial Error Model, Tingkat Pengangguran Terbuka.

\section{PENDAHULUAN}

$\mathrm{R}$ EGRESI spasial merupakan salah satu metode statistik yang digunakan untuk memodelkan suatu permasalahan yang dipengaruhi oleh beberapa faktor tertentu dengan memperhatikan efek lokasi atau tempat [1]. Di dalam sebuah observasi yang mengandung informasi ruang atau spasial (data spasial), maka pemodelan tidak tepat apabila hanya menggunakan analisis regresi linier berganda. Pemodelan menggunakan analisis regresi linier berganda dapat menyebabkan terjadinya pelanggaran asumsi seperti nilai residual menjadi berkorelasi dengan yang lainnya dan varians residual tidak konstans. Data yang memiliki informasi mengenai ruang atau spasial apabila diabaikan dalam pemodelan, maka bisa mengakibatkan koefisien regresi menjadi bias atau tidak konsisten, nilai $\mathrm{R}^{2}$ atau koefisien determinasi akan berlebihan serta kesimpulan yang ditarik tidak tepat dikarenakan pemodelan yang dilakukan tidak tepat.

Dalam penelitian ini, akan dilakukan pemodelan regresi spasial mengenai faktor-faktor yang mempengaruhi tingkat pengangguran terbuka di Provinsi Jawa Timur tahun 2015. Penelitian ini bertujuan untuk menggambarkan karakteristik faktor-faktor yang diduga mempengaruhi tingkat pengangguran terbuka di Provinsi Jawa Timur tahun 2015 kemudian dilanjutkan dengan pemodelan regresi spasial. Aspek spasial ini diduga sebagai salah satu faktor yang berpengaruh terhadap tingkat pengangguran terbuka

Indonesia merupakan negara yang memiliki jumlah penduduk yang sangat padat. Tahun 2015, Provinsi Jawa Timur merupakan provinsi yang memiliki jumlah penduduk terbesar kedua setelah Provinsi Jawa Barat. Jumlah penduduk yang ada di Provinsi Jawa Timur mencapai 38.847.000 jiwa [2]. Jumlah penduduk di Provinsi Jawa Timur yang sangat tinggi ini mempunyai kenaikan secara signifikan. Jumlah penduduk di Provinsi Jawa Timur yang semakin padat ini menyebabkan jumlah angkatan kerja menjadi bertambah banyak pula. Jumlah angkatan kerja yang sangat banyak ini tidak sebanding dengan jumlah penduduk yang sudah bekerja. Jumlah penduduk yang sudah bekerja lebih sedikit apabila dibandingkan dengan jumlah angkatan kerja sehingga menyebabkan terjadinya pengangguran terbuka.

Tingkat pengangguran terbuka yang ada di Provinsi Jawa Timur mengalami kenaikan untuk setiap tahunnya. Tahun 2014 ke tahun 2015, persentase angka pengangguran terbuka di Provinsi Jawa Timur yang semula 4,19\% berubah menjadi 4,47\% untuk tahun 2015 [3]. Tingginya persentase tingkat pengangguran terbuka di Provinsi Jawa Timur disebabkan oleh beberapa faktor yang diantaranya adalah laju pertumbuhan penduduk. Semakin meningkat untuk setiap tahunnya sehingga menyebabkan jumlah angkatan kerja juga semakin banyak namun tidak diimbangi dengan jumlah penduduk yang sudah bekerja yang meningkat pula tetapi tidak sebanyak dengan peningkatan jumlah angkatan kerja.

Banyak peneliti yang menggunakan metode regresi spasial untuk menganalisis fenomena tingkat pengangguran terbuka. Sebuah penelitian mengenai Pendekatan Regresi Spasial dalam Pemodelan Tingkat Pengangguran Terbuka dilakukan di tahun 2012 oleh Mariana[4]. Marsono melakukan penelitian mengenai Pemodelan Pengangguran Terbuka di Indonesia dengan Pendekatan Ekonometrika Spasial Data Panel tahun 2013 [5]. Bulan Juni 2015, Rita Rahmawati, Diah Safitri dan Octafinnanda Ummu Fairuzdhiya melakukan penelitian tentang Analisis Spasial Pengaruh Tingkat Pengangguran 
terhadap Kemiskinan di Indonesia (Studi Kasus Provinsi Jawa Tengah) [6].

\section{TINJAUAN PUSTAKA}

\section{A. Analisis Regresi Linier Berganda}

Analisis regresi linier berganda merupakan persamaan matematik yang menjelaskan hubungan variabel respon $(Y)$ dengan variabel prediktor $\left(X_{1}, X_{2}, \ldots, X_{k}\right)$ dimana variabel prediktor yang mempengaruhinya lebih dari satu jumlahnya [7]. Postulasi model regresi linier berganda dengan $k$ buah variabel prediktor yang banyak ditemukan secara umum adalah sebagai berikut ini.

$$
Y=\beta_{0}+\beta_{1} X_{1}+\beta_{2} X_{2}+\cdots+\beta_{k} X_{k}+\varepsilon
$$

Berdasarkan persamaan (1) diatas apabila disederhanakan maka menjadi $\boldsymbol{Y}=\boldsymbol{X} \boldsymbol{\beta}+\boldsymbol{\varepsilon}$ dimana $\boldsymbol{Y}$ adalah variabel respon (vektor berukuran $n x l$ ), $\boldsymbol{\beta}$ adalah parameter regresi (vektor berukuran $(k+1) x l), \quad \boldsymbol{X}$ adalah variabel prediktor (matrik berukuran $n x(k+1)), \boldsymbol{\varepsilon}$ adalah residual dengan asumsi identik, independen dan berdistribusi normal dengan mean nol dan varians $\sigma^{2}$ (vektor berukuran $n x l$ ). Berdasarkan persamaan (1) diatas dapat diperoleh penaksir OLS untuk $\beta$ adalah sebagai berikut;

$$
\hat{\beta}=\left(X^{T} X\right)^{-1} X^{T} Y
$$

Pengujian signifikansi parameter secara serentak dan parsial serta pemeriksaan multikolinearitas dilakukan setelah didapatkan model regresi linier berganda. Nilai statistik uji pada pengujian signifikansi parameter secara serentak dihasilkan dari tabel ANOVA terkoreksi berikut ini.

Tabel 1.

Tabel ANOVA Terkoreksi

\begin{tabular}{cccc}
\hline \hline Sumber & $\mathrm{DF}$ & $\begin{array}{l}\text { Sum of } \\
\text { Square }\end{array}$ & Mean of Square \\
\hline Regresi & $\mathrm{k}+1$ & $\beta^{T} X^{T} Y$ & $\frac{\beta^{T} X^{T} Y}{\mathrm{k}+1}$ \\
$\left(\beta_{0}, \beta_{1}, \cdots, \beta_{k}\right)$ & $\mathrm{n}-\mathrm{k}-$ & $Y^{T} Y$ & $\frac{Y^{T} Y-\beta^{T} X^{T} Y}{\mathrm{n}-\mathrm{k}-1}$ \\
Residual & 1 & $-\beta^{T} X^{T} Y$ & \\
Total & $\mathrm{n}$ & $Y^{T} Y$ & \\
\hline \hline
\end{tabular}

\section{B. Analisis Regresi Spasial}

Pemodelan spasial sangat erat dengan proses autoregressive ditunjukkan dengan adanya hubungan ketergantungan antar sekumpulan pengamatan atau lokasi [8]. Model Spatial Autoregressive merupakan model yang mengkombinasikan model regresi sederhana dengan lag spasial pada variabel dependen menggunakan data cross section [9]. Model ini terbentuk apabila $\boldsymbol{\rho} \neq 0$ dan $\lambda=0$.

$$
Y=\rho W Y+X \beta+\varepsilon
$$

Dimana $\boldsymbol{Y}$ adalah vektor variabel respon $(n x l), \boldsymbol{X}$ adalah matrik variabel prediktor $(n x(k+1)), \boldsymbol{U}$ adalah vektor eror pada persamaan $\boldsymbol{Y}(n x l), \boldsymbol{\varepsilon}$ adalah vektor eror pada persamaan, $\boldsymbol{U}$ adalah mempunyai distribusi normal dengan mean nol dan varians $\sigma^{2} I(n x l), \rho$ adalah parameter koefisien spasial lag variabel dependen, $\lambda$ adalah parameter koefisien spasial lag pada eror, $\boldsymbol{W}$ adalah matrik pembobot untuk pengaruh spasial antar lokasi dalam model (I).
Estimasi parameter spatial autoregressive model menggunakan metode maximum likelihood adalah sebagai berikut;

$\ln L\left(\beta, \rho, \sigma^{2} \mid Y, X\right)=-\frac{n}{2} \ln (2 \pi)-\frac{n}{2} \ln \sigma^{2}+$ $\ln |I-\rho W|-\frac{1}{2 \sigma^{2}}(Y-\rho W Y-X \beta)^{T}(Y-\rho W Y-X \beta)$ (4)

Estimasi parameter untuk nilai $\boldsymbol{\beta}$ adalah,

$$
\hat{\beta}=\left(X^{T} X\right)^{-1} X^{T}(1-\rho W) Y
$$

Model spasial eror ditemukan eror pada korelasi spasialnya. Model spasial eror ini terbentuk apabila $\lambda \neq 0$ dan $\rho=0$ sehingga model ini kemudian mengasumsikan bahwa proses autoregressive hanya pada eror model saja [9].

$$
Y=X \beta+\lambda W U+\varepsilon
$$

Estimasi parameter maximum likelihood terhadap model SEM mempunyai rumus sebagai berikut;

$L=$

$$
\begin{aligned}
& -\frac{n}{2} \ln (2 \pi)-\frac{n}{2} \ln \left(\sigma^{2}\right)+\ln |I-\lambda W|- \\
& \frac{(Y-X \beta)^{T}(I-\lambda W)^{T}(I-\lambda W)(Y-X \beta)}{2 \sigma^{2}}
\end{aligned}
$$

Estimasi parameter $\beta$ pada spatial error model adalah, $\hat{\beta}=\left(X^{T}(I-\lambda W)^{T}(I-\lambda W) X\right)^{-1}\left(X^{T}(I-\lambda W)^{T}(I-\right.$ $\lambda W) Y)$

Pengujian lagrange multiplier digunakan sebagai dasar untuk memilih model regresi spasial yang sesuai. LM eror signifikan maka model yang sesuai adalah SEM dan apabila LM lag signifikan maka model yang sesuai adalah SAR

Hipotesis yang digunakan pada LM lag adalah,

$H_{0}: \rho=0$ (tidak ada dependensi spasial lag)

$H_{1}: \rho \neq 0$ (ada dependensi spasial lag)

Statistik uji yang digunakan pada LM lag adalah,

$L M \operatorname{lag}=\frac{\left(\frac{e^{T} W Y}{S^{2}}\right)^{2}}{\frac{\left((W X \boldsymbol{\beta})^{T} M(W X \boldsymbol{\beta})+T S^{2}\right)}{S^{2}}}$

Uji hipotesis lagrange multiplier error berikut,

$H_{0}: \lambda=0$ (tidak ada dependensi spasial eror)

$H_{1}: \lambda \neq 0 \quad$ (ada dependensi spasial eror)

Statistik uji yang digunakan pada LM eror adalah,

$$
L M \text { error }=\frac{\left(\frac{e^{T} W Y}{\sigma^{2}}\right)^{2}}{\operatorname{tr}\left(\left(\boldsymbol{W}^{T}+W\right) W\right)}
$$

Lagrange multiplier lag dan error tolak $H_{0}$ apabila nilai LM lag $>X_{(\alpha, 1)}^{2}$ dan nilai $L M$ error $>X_{(\alpha, 1)}^{2}$.

Efek dependensi spasial membuat nilai autokorelasi spasial menjadi positif terhadap residual. Efek dependensi spasial dilakukan menggunakan pengujian Moran's I. Hipotesis yang digunakan adalah,

$H_{0}: I=0$ (tidak ada autokorelasi antar lokasi)

$H_{1}: I \neq 0$ (ada autokorelasi antar lokasi)

Statistik uji yang digunakan adalah sebagai berikut;

$Z_{\text {hitung }}=\frac{I-I_{0}}{\sqrt{\operatorname{var}(I)}} \sim N(0,1)$

Heterogenitas spasial merupakan efek spasial yang terjadi pada antar lokasi yang mempunyai struktur yang berbeda. Efek ini diuji menggunakan Breusch Pagan. Hipotesis yang digunakan adalah,

$\mathrm{H}_{0}: \sigma_{1}^{2}=\sigma_{2}^{2}=\cdots=\sigma_{n}^{2}=\sigma^{2}($ Kesamaan varians / homokedastisitas) 
$\mathrm{H}_{0}$ : paling tidak ada satu $\sigma_{i}^{2} \neq \sigma^{2}$ (Perbedaan varians / heterokedastisitas)

Statistik uji yang digunakan adalah,

$$
B P=\frac{1}{2} f^{T} \boldsymbol{A}\left(\boldsymbol{A}^{T} \boldsymbol{A}\right)^{-1} \boldsymbol{A}^{T} f \sim X_{k}^{2}
$$

Dimana A merupakan matrik berukuran $\mathrm{nx}(\mathrm{k}+2)$ berisi vektor yang sudah dinormal standarkan untuk setiap observasi. Pengambilan keputusan pada Moran's I akan tolak $H_{0}$ apabila $\left|Z_{\text {hitung }}\right|>Z_{\alpha / 2}$. Pengambilan keputusan pada Breusch-Pagan akan tolak $H_{0}$ apabila nila $B P$ lebih dari nilai $X_{k}^{2}$ atau nilai $c h i-$ square.

Matriks pembobot spasial merupakan hubungan yang menggambarkan antar wilayah. Matriks pembobot spasial digambarkan secara umum dalam bentuk matrik sebagai berikut.

$$
W=\left[\begin{array}{ccccc}
W_{11} & W_{12} & W_{13} & \cdots & W_{1 n} \\
W_{21} & W_{22} & W_{23} & \cdots & W_{2 n} \\
\vdots & \vdots & \vdots & \ddots & \vdots \\
W_{n 1} & W_{n 2} & W_{n 3} & \cdots & W_{n n}
\end{array}\right]
$$

Persinggungan yang digunakan adalah sisi sudut (Queen Contiguity) dan sisi (Rook Contiguity). Persinggungan ini mendefinisikan $W_{i j}=1$ untuk wilayah yang bersinggungan secara sisi maupun sudut dan $W_{i j}=0$ untuk wilayah lainnya.

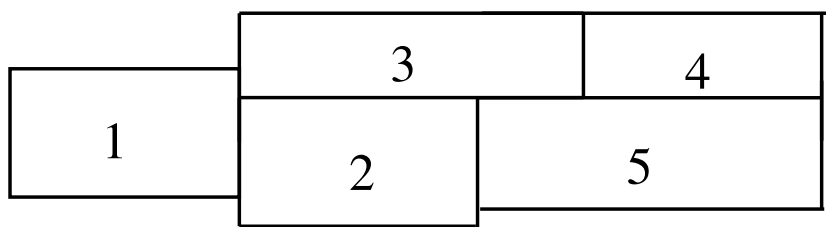

Gambar 1. Ilustrasi Lima Wilayah dalam suatu Peta.

Susunan matriks untuk Queen Contiguity yang belum dinormalisasi baris berukuran $5 \times 5$ adalah berikut;

$$
W_{\text {QUEEN }}=\left[\begin{array}{lllll}
0 & 0 & 0 & 0 & 0 \\
0 & 0 & 1 & 0 & 1 \\
0 & 1 & 0 & 1 & 0 \\
0 & 0 & 1 & 0 & 1 \\
0 & 1 & 0 & 1 & 0
\end{array}\right]
$$

Susunan matriks untuk Rook Contiguity yang berlum dinormalisasi secara baris berukuran $5 \times 5$ adalah berikut;

$$
W_{\text {ROOK }}=\left[\begin{array}{lllll}
0 & 1 & 1 & 0 & 0 \\
1 & 0 & 1 & 0 & 1 \\
1 & 1 & 0 & 1 & 1 \\
0 & 0 & 1 & 0 & 1 \\
0 & 1 & 1 & 1 & 0
\end{array}\right]
$$

\section{Pemeriksaan Asumsi Regresi}

Pemeriksaan multikolinearitas merupakan adanya korelasi yang kuat antar beberapa atau bahkan semua variabel prediktor. Model regresi yang dibentuk mengandung kasus multikolinearitas maka hal tersebut menyebabkan hasil dari sampel yang ada tidak dapat ditarik kesimpulan. Cara mendeteksi adanya kasus multikolinearitas dengan melihat nilai Variance Inflation Factor yakni lebih besar dari 10. Cara untuk mendapatkan nilai VIF dengan rumus berikut.

$$
V I F_{j}=\frac{1}{1-R_{j}^{2}}
$$

Dimana $\mathrm{R}_{\mathrm{j}}^{2}$ didapatkan dari hasil meregresikan $\mathrm{X}_{\mathrm{j}}$ terhadap variabel prediktor selain $\mathrm{X}_{\mathrm{j}}$. Cara untuk mengatasi kasus multikolinearitas yakni menggunakan metode backward [10].
Asumsi saling bebas atau independen atau pengujian autokorelasi residual dilakukan untuk mengetahui ada atau tidaknya korelasi pada residual data. Hipotesis yang digunakan dalam uji Durbin Watson untuk asumsi independen adalah berikut;

$\mathrm{H}_{0}: \rho=0$ (tidak ada korelasi residual)

$H_{1}: \rho \neq 0$ (ada korelasi residual)

Statistik uji yang digunakan dalam pengujian Durbin Watson adalah berikut ini.

$d_{\text {hitung }}=\frac{\sum_{i=1}^{n}\left(e_{i}-e_{i-1}\right)^{2}}{\sum_{i=1}^{n} e_{i}^{2}}$

Hasil pengujian Durbin Watson akan tolak $H_{0}$ apabila $d_{\text {hitung }} \leq d_{L, \alpha / 2}$ atau $d_{\text {hitung }} \geq\left(4-d_{L, \alpha / 2}\right)$. Asumsi berdistribusi normal digunakan untuk mengetahui residual berdistribusi normal atau tidak. Hipotesis yang digunakan dalam pengujian Shapiro Wilk adalah berikut;

$H_{0}$ : residual berdistribusi normal

$H_{1}$ : residual tidak berdistribusi normal

Statistik uji yang digunakan dalam pengujian Shapiro Wilk adalah berikut;

$$
\begin{aligned}
& T_{3}=\frac{1}{\sum_{i=1}^{n}\left(x_{i}-\bar{x}\right)^{2}}\left[\sum_{j=1}^{k} \sum_{i=1}^{n} a_{j}\left(x_{n-i+1}-x_{i}\right)\right]^{2} \\
& \text { Shapiro Wilk akan tolak } H_{0} \text { apabila } \mathrm{p}<\alpha .
\end{aligned}
$$

\section{Tingkat Pengangguran Terbuka}

Tingkat pengangguran terbuka merupakan persentase jumlah pengangguran terhadap jumlah angkatan kerja. Tingkat pengangguran terbuka memiliki kegunaan untuk mengindikasikan besarnya persentase angkatan kerja yang termasuk dalam pengangguran. Rumus yang digunakan untuk bisa mengetahui besarnya persentase tingkat pengangguran kerja adalah sebagai berikut ini.

$T P T=\frac{\text { Jumlah Pengangguran }}{\text { Jumlah Angkatan Kerja }} \times 100 \%$

Semakin pesatnya laju pertumbuhan penduduk mengakibatkan persaingan untuk mendapatkan pekerjaan semakin ketat. Ini menyebabkan tidak semua angkatan kerja dapat diserap oleh lapangan kerja. Sebagai akibatnya yakni terjadi pengangguran yang tidak terelakan lagi.

\section{METODOLOGI PENELITIAN}

\section{A. Sumber data}

Data yang akan digunakan dalam penelitian adalah data sekunder yang diperoleh dari website Badan Pusat Statistik Provinsi Jawa Timur, publikasi Keadaan Angkatan Kerja di Jawa Timur Agustus 2015 serta publikasi Produk DOmestik Regional Bruto Kabupaten / Kota Menurut Lapangan Usahan 2011-2015. Unit observasi yang digunakan berupa data per kabupaten dan kota sejumlah 38 .

\section{B. Variabel Penelitian}

Variabel yang akan digunakan dalam penelitian kali ini adalah sebagai berikut.

Tabel 2. Variabel Penelitian

\begin{tabular}{cc}
\hline \hline Variabel & Keterangan \\
\hline $\mathrm{Y}$ & Tingkat Pengangguran Terbuka \\
$\mathrm{X}_{1}$ & Persentase Penduduk Miskin $(\%)$ \\
\hline \hline
\end{tabular}




\begin{tabular}{cc}
\hline \hline $\mathrm{X}_{2}$ & $\begin{array}{c}\text { Distribusi PDRB Atas Dasar Harga Berlaku Menurut } \\
\text { Lapangan Usaha Jasa Lainnya (\%) }\end{array}$ \\
& Persentase Jumlah Angkatan Kerja dengan Pendidikan \\
$\mathrm{X}_{3}$ & Tertinggi Tingkat Diploma I / II / III / Akademi (\%) \\
\hline \hline
\end{tabular}

Berdasarkan variabel penelitian pada Tabel 1, data yang digunakan dalam penelitian memiliki struktur sebagai berikut.

Tabel 3.

\begin{tabular}{ccccc}
\multicolumn{5}{c}{ Struktur Data yang Digunakan } \\
\hline \hline Kabupaten / & \multicolumn{4}{c}{ Variabel } \\
\cline { 2 - 5 } Kota & $\mathrm{Y}$ & $\mathrm{X}_{1}$ & $\mathrm{X}_{2}$ & $\mathrm{X}_{3}$ \\
1 & $\mathrm{Y}_{1}$ & $\mathrm{X}_{1,1}$ & $\mathrm{X}_{2,1}$ & $\mathrm{X}_{3,1}$ \\
2 & $\mathrm{Y}_{2}$ & $\mathrm{X}_{1,2}$ & $\mathrm{X}_{2,2}$ & $\mathrm{X}_{3,2}$ \\
$\cdot$ & $\cdot$ & $\cdot$ & $\cdot$ & $\cdot$ \\
$\cdot$ &. & $\cdot$ & $\cdot$ & $\cdot$ \\
$\cdot$ & $\cdot$ & $\cdot$ & $\cdot$ & $\cdot$ \\
38 & $\mathrm{Y}_{38}$ & $\mathrm{X}_{1,38}$ & $\mathrm{X}_{2,38}$ & $\mathrm{X}_{3,38}$ \\
\hline \hline
\end{tabular}

\section{Langkah Analisis}

Langkah analisis yang digunakan dalam penelitian kali ini adalah:

1. Mendeskripsikan karakteristik dari variabel dependen dan independen menggunakan peta tematik.

2. Memodelkan regresi spasial berdasarkan faktor-faktor yang mempengaruhi tingkat pengangguran terbuka di Provinsi Jawa Timur.

Tahapan dalam melakukan pemodelan regresi spasial terdiri dari:

a. Menetapkan unit observasi yakni kabupaten dan kota, variabel dependen yaitu tingkat pengangguran terbuka dan variabel lainnya sebagai variabel independen.

b. Melakukan pemeriksaan multikolinearitas dengan melihat nilai VIF (Variance Inflation Factor).

c. Melakukan pemodelan regresi linier berganda menggunakan metode OLS (Ordinary Least Square).

d. Melakukan pemeriksaan asumsi residual yakni independen dengan Durbin Watson serta berdistribusi normal menggunakan Shapiro Wilk.

e. Menentukan pembobot spasial menggunakan persinggungan rook contiguity dan queen contiguity yang sudah dinormalisasikan secara baris.

f. Melakukan pengujian dependensi spasial menggunakan Moran's I dan pengujian heterogenitas spasial menggunakan Breusch-Pagan.

g. Mengidentifikasikan pola spasial menggunakan lagrange multiplier lag dan lagrange multiplier error.

h. Melakukan pemodelan Spatial Autoregressive Model dan Spatial Error Model.

i. Menentukan model regresi terbaik menggunakan nilai AIC (Akaike Information Criterion).

Berdasarkan langkah analisis diatas, maka spesifikasi model dalam penelitian ini adalah sebagai berikut.

a. Spatial Autoregressive Model

$$
\hat{Y}_{i}=\beta_{0}+\rho \sum_{j=1, i \neq j}^{38} W_{i j} Y_{j}+\beta_{1} X_{1 i}+\beta_{2} X_{2 i}+\beta_{3} X_{3 i}
$$

b. Spatial Error Model

$$
\hat{Y}_{i}=\gamma_{0}+\lambda \sum_{j=1, i \neq j}^{38} W_{i j} U_{j}+\gamma_{1} X_{1 i}+\gamma_{2} X_{2 i}+\gamma_{3} X_{3 i}
$$

\section{ANALISIS DAN PEMBAHASAN}

\section{A. Karakteristik Faktor-faktor yang Mempengaruhi Tingkat} Pengangguran Terbuka di Provinsi Jawa Timur Tahun 2015

Karakteristik faktor-faktor yang diduga mempengaruhi tingkat pengangguran terbuka di Provinsi Jawa Timur tahun 2015 dapat ditunjukkan menggunakan peta tematik. Setiap variabel dikelompokkan dalam tiga kategori yakni rendah, sedang dan tinggi. Batas-batas untuk setiap kategori didapatkan dari nilai jangkauan terbesar.

Variabel distribusi PDRB atas dasar harga berlaku menurut lapangan usaha jasa lainnya memiliki jumlah kategori rendah paling banyak diantara variabel lainnya. Kota Malang merupakan satu-satunya kawasan kabupaten dan kota di Provinsi Jawa Timur yang termasuk dalam kategori tinggi untuk variabel persentase jumlah angkatan kerja dengan pendidikan tertinggi tingkat Diploma I / II / III / Akademi.

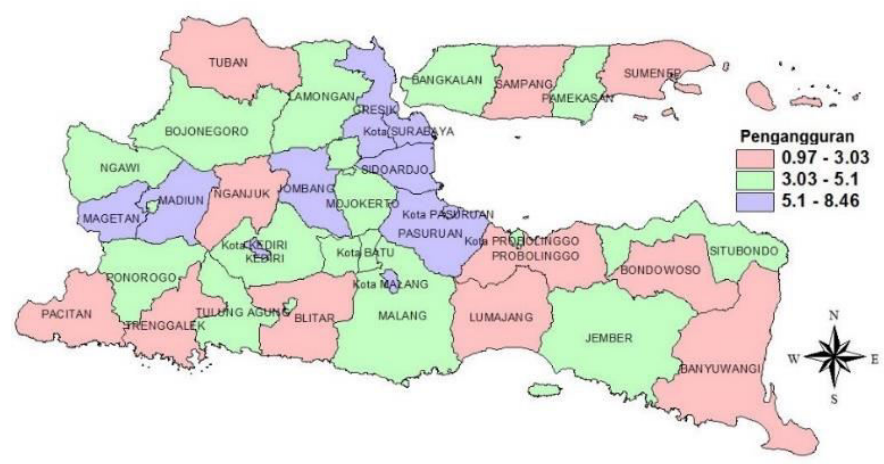

Gambar 2. Peta Tematik Tingkat Pengangguran Terbuka di Provinsi Jawa Timur Tahun 2015.

Angka pengangguran terbuka di Provinsi Jawa Timur tahun 2015 dengan kategori tinggi banyak terjadi pada wilayah Provinsi Jawa Timur di bagian timur laut seperti Kabupaten Magetan, Kabupaten Madiun, Kabupaten Jombang, Kabupaten Sidoarjo, Kabupaten Pasuruan, Kabupaten Gresik, Kota Surabaya, Kota Kediri, Kota Malang serta Kota Pasuruan. Angka pengangguran terbuka untuk kategori sedang dan rendah memiliki persebaran yang acak untuk setiap kabupaten maupun kota di Provinsi Jawa Timur tahun 2015. Persebaran untuk kategori sedang dan rendah tersebut terjadi secara berselang-seling satu sama lain misalnya seperti Kabupaten Banyuwangi termasuk dalam kategori rendah kemudian Kabupaten Jember ada di kategori sedang lalu Kabupaten Lumajang tergolong kategori rendah dan Kabupaten Malang masuk kategori sedang. 
B. Pemodelan Faktor-faktor yang Mempengaruhi Tingkat Pengangguran Terbuka di Provinsi Jawa Timur Tahun 2015 Menggunakan Regresi Spasial

Analisis regresi linier berganda digunakan untuk mengetahui hubungan antara variabel dependen dan variabel independen secara linier.

Tabel 4.

Regresi Linier Berganda

\begin{tabular}{cccc}
\hline \multicolumn{4}{c}{ Regresi Linier Berganda } \\
\hline Koefisien & Estimasi & P-value & VIF \\
\hline Konstanta & 5,82115 & 0,000 & \\
$\mathrm{X}_{1}$ & $-0,14091$ & 0,037 & 1,81752 \\
$\mathrm{X}_{2}$ & $-0,20156$ & 0,069 & 1,18441 \\
$\mathrm{X}_{3}$ & 0,39188 & 0,136 & 1,6943 \\
& $\mathrm{~F}=5,681$ & \\
& P-value $=0,002893$ &
\end{tabular}

Variabel persentase penduduk miskin, distribusi PDRB atas dasar harga berlaku menurut lapangan usaha jasa lainnya serta persentase jumlah angkatan kerja dengan pendidikan tertinggi tingkat diploma I / II / III / akademi memiliki nilai VIF kurang dari 10. Ini berarti sudah bebas dari multikolinearitas. Nilai $P$ value kurang dari taraf signifikansi $15 \%$. Ini menunjukkan bahwa semua variabel signifikan apabila disubsitusikan ke persamaan regresi. Model regresi linier berganda yang terbentuk adalah.

$$
\hat{Y}=5,82-0,1409 X_{1}-0,202 X_{2}+0,392 X_{3}
$$

Tiga variabel prediktor tersebut tidak semuanya memberikan pengaruh signifikan secara serentak terhadap variabel respon sebab nilai $P$-vaue $(0,002893)$ lebih kecil dari $\alpha(0,15)$. Tiga variabel tersebut juga memberikan pengaruh yang signifikan secara parsial kepada variabel respon pada taraf signifikansi $15 \%$.

Tabel 5.

Pengujian Asumsi Regresi Linier

\begin{tabular}{ccc}
\hline \hline Pengujian & Nilai & $P$-value \\
\hline Shapiro Wilk & 0,96474 & 0,3957 \\
Durbin Watson & 2,0638 & 0,8853 \\
\hline \hline
\end{tabular}

Nilai $P$-value pada pengujian Shapiro Wilk lebih besar dari taraf signifikansi $15 \%$. Ini memberikan kesimpulan bahwa residual data yang digunakan berdistribusi normal. Pengujian Durbin Watson memiliki nilai $P$-value lebih dari taraf signifikansi $15 \%$. Ini berarti model regresi yang dibuat tidak ada korelasi antara satu residual dengan residual lainnya.

Model analisis regresi linier berganda yang terbentuk sudah menjelaskan variabel tingkat pengangguran terbuka sebesar $33,39 \%$ dan sisanya $66,61 \%$ dijelaskan oleh variabel lain yang terdapat di luar model dimana variabel lain ini memuat unsur spasial sebab satu lokasi dengan lokasi lainnya diduga memiliki hubungan kedekatan satu sama lain.
Tabel 6.

Hasil Pengujian Efek Spasial dengan Rook Contiguity

\begin{tabular}{cccc}
\hline \hline No & Pengujian & Nilai & P-value \\
\hline 1 & Moran's I & 2 & 0,0455 \\
2 & Breusch Pagan & 1,5842 & 0,663 \\
3 & Lagrange Multiplier (Lag) & 2,095 & 0,1478 \\
4 & Lagrange Multiplier (Error) & 2,4472 & 0,1177 \\
5 & Robust Lagrange Multiplier (Lag) & 0,0006 & 0,9791 \\
6 & Robust Lagrange Multiplier (Error) & 0,3529 & 0,5525 \\
\hline \hline
\end{tabular}

Pengujian Moran's I kurang dari taraf signifikan 15\% berarti setiap kabupaten dan kota di Provinsi Jawa Timur yang saling berdekatan lokasinya memiliki hubungan satu sama lain dengan sangat besar. Hubungan ini nantinya akan dijelaskan dalam sebuah pemodelan regresi spasial. Nilai P-value untuk pengujian Breusch Pagan melebihi dari taraf signifikan 15\% berarti setiap kabupaten dan kota di Provinsi Jawa Timur memiliki kesamaan satu sama lain.

Pengujian lagrange multiplier lag menunjukkan hasil bahwa nilai P-value kurang dari taraf signifikan $15 \%$ berarti $\rho \neq 0$ yang memiliki makna bahwa spatial autoregressive model bisa digunakan untuk pemodelan regresi spasial. Pengujian robust lagrange multiplier lag menunjukkan hasil bahwa nilai P-value lebih dari taraf signifikan $15 \%$ akan menghasilkan nilai AIC yang cukup tinggi serta parameter koefisien spasial lag tidak signifikan. Spatial autoregressive model yang terbentuk.

$$
\begin{gathered}
\hat{Y}_{i}=4,724983+0,24262 \sum_{j=1, i \neq j}^{38} W_{i j} Y_{j}- \\
0,129954 X_{1 i}-0,195824 X_{2 i}+0,342456 X_{3 i}
\end{gathered}
$$

Nilai $P$-value pengujian lagrange multiplier error kurang dari nilai taraf signifikansi $15 \%$ berarti $\lambda \neq 0$ yang memiliki makna pemodelan regresi spasial menggunakan spatial error model bisa dilakukan sebagai analisis lanjutan. Pengujian robust lagrange multiplier error menunjukkan hasil bahwa nilai P-value lebih dari taraf signifikan $15 \%$ akan menghasilkan nilai AIC yang cukup tinggi. Pemodelan regresi spasial pada error yang terbentuk adalah.

$$
\begin{gathered}
\hat{Y}_{i}=6,286781+0,30785 \sum_{j=1, i \neq j}^{38} W_{i j} U_{j}- \\
0,166038 X_{1 i}-0,196714 X_{2 i}
\end{gathered}
$$

Tabel 7.

Hasil Pengujian Efek Spasial dengan Queen Contiguity

\begin{tabular}{cccc}
\hline \hline No & Pengujian & Nilai & P-value \\
\hline 1 & Moran's I & 1,8908 & 0,05865 \\
2 & Breusch Pagan & 1,5842 & 0,663 \\
3 & Lagrange Multiplier (Lag) & 1,7013 & 0,1921 \\
4 & Lagrange Multiplier (Error) & 2,1129 & 0,1461 \\
5 & Robust Lagrange Multiplier (Lag) & 0,0068 & 0,9341 \\
6 & Robust Lagrange Multiplier (Error) & 0,4184 & 0,5177 \\
\hline \hline
\end{tabular}

Pengujian Moran's I $(0,05865)$ kurang dari taraf signifikan 0,15 berarti setiap kabupaten dan kota di Provinsi Jawa Timur yang saling berdekatan lokasinya memiliki hubungan satu sama lain dengan sangat besar. Hubungan ini nantinya akan dijelaskan dalam sebuah pemodelan regresi spasial. Nilai Pvalue $(0,663)$ untuk pengujian Breusch Pagan melebihi dari taraf signifikan 0,15 berarti setiap kabupaten dan kota di Provinsi Jawa Timur memiliki kesamaan satu sama lain. 
Pengujian lagrange multiplier lag menunjukkan hasil bahwa nilai P-value $(0,1921)$ lebih dari taraf signifikan 0,15 berarti $\rho=0$ yang memiliki makna bahwa spatial autoregressive model tidak bisa digunakan untuk pemodelan regresi spasial. Pengujian robust lagrange multiplier lag menunjukkan hasil bahwa nilai P-value $(0,9341)$ lebih dari taraf signifikan 0,15 akan menghasilkan nilai AIC yang cukup tinggi. Spatial autoregressive model yang terbentuk.

$$
\widehat{Y}_{i}=4,835905+0,21829 \sum_{j=1, i \neq j}^{38} W_{i j} Y_{j}-
$$$$
0,131318 X_{1 i}-0,196703 X_{2 i}+0,348417 X_{3 i}
$$

Nilai $P$-value $(0,1461)$ pengujian lagrange multiplier error kurang dari nilai taraf signifikansi 0,15 berarti $\lambda \neq 0$ yang memiliki makna pemodelan regresi spasial menggunakan spatial error model bisa dilakukan sebagai analisis lanjutan. Pengujian robust lagrange multiplier error menunjukkan hasil bahwa nilai $P$-value $(0,5177)$ lebih dari taraf signifikan 0,15 akan menghasilkan nilai AIC yang cukup tinggi Pemodelan regresi spasial pada error yang terbentuk adalah.

$$
\begin{aligned}
& \hat{Y}_{i}=6,272017+0,28661 \sum_{j=1, i \neq j}^{38} W_{i j} U_{j}- \\
& 0,165825 X_{1 i}-0,197991 X_{2 i}
\end{aligned}
$$

Kelima pemodelan tersebut perlu dicari kebaikan modelnya supaya bisa menentukan model mana yang sangat cocok untuk diterapkan pada variabel-variabel tersebut. Ukuran kebaikan model bisa menggunakan nilai AIC.

Tabel 8.

Nilai AIC Model Regresi

\begin{tabular}{cccc}
\hline \hline \multirow{2}{*}{ No } & Model Regresi & AIC & \multirow{2}{*}{ AIC Queen } \\
& & Rook & Aultiple Linier Regression \\
1 & Spatial Autoregreesive Model & 143,02 & 143,02 \\
2 & Spatial Error Model & 142,39 & 143,37 \\
3 & 142,78 \\
\hline \hline
\end{tabular}

Tingkat pengangguran terbuka menggunakan spatial error model berbobot rook contiguity merupakan model yang terbaik sebab memiliki nilai AIC terendah diantara multiple linier regression model serta spatial autoregressive model dengan nilai AIC sebesar 142,39. Setiap kabupaten dan kota memiliki bentuk spatial error model yang berbeda-beda dipengaruhi matrik pembobot berdekatan antara satu kabupaten dan kota dengan kabupaten dan kota lainnya sebagai objek pengamatan. Spatial error model untuk Kota Surabaya.

$$
\begin{aligned}
& \hat{Y}_{\text {Kota Surabaya }}= \\
& 6,286781+ \\
& 0,30785\left(U_{\text {Kabupaten Sidoarjo }}+U_{\text {Kabupaten Gresik }}\right)- \\
& 0,166038 X_{1 \text { Kota Surabaya }}-0,196714 X_{2 \text { Kota Surabaya }} \text { (22) }
\end{aligned}
$$

Spatial error model untuk Kota Surabaya memiliki pengertian bahwa variabel persentase penduduk miskin dan variabel distribusi PDRB atas dasar harga berlaku menurut lapangan usaha jasa lainnya mengalami kenaikan satu satuan sedangkan untuk variabel lainnya dianggap konstan, maka angka tingkat pengangguran terbuka akan mengalami penurunan sebesar 0,362752 persen. Kedua nilai error dari Kabupaten Sidoarjo dan Kabupaten Gresik berpengaruh terhadap spatial error model di Kota Surabaya sebesar 0,30785 persen. Kabupaten Sidoarjo serta Kabupaten Gresik memiliki peranan yang besar dalam menurunkan tingkat pengangguran terbuka di Kota Surabaya apabila dibandingkan dengan kabupaten dan kota lainnya. Hal ini terjadi sebab adanya dependensi spasial yang artinya kabupaten dan kota yang saling berdekatan memiliki hubungan atau pengaruh antara satu sama lain

\section{KESIMPULAN DAN SARAN}

\section{A. Kesimpulan}

Berdasarkan hasil analisis dan pembahasan yang telah dijelaskan pada bab sebelumnya mengenai faktor-faktor yang mempengaruhi tingkat pengangguran terbuka di Provinsi Jawa Timur tahun 2017, maka diambil kesimpulan seperti berikut.

1. Angka pengangguran terbuka di Provinsi Jawa Timur tahun 2015 dengan kategori tinggi banyak terjadi pada wilayah Provinsi Jawa Timur di bagian timur laut. Angka pengangguran terbuka untuk kategori sedang dan rendah memiliki persebaran yang merata untuk setiap kabupaten maupun kota di Provinsi Jawa Timur tahun 2015.

2. Spatial error model menggunakan matriks pembobot rook contiguity merupakan pemodelan terbaik terhadap faktorfaktor yang mempengaruhi tingkat pengangguran terbuka di Provinsi Jawa Timur tahun 2015 sebab memiliki nilai AIC yang paling kecil diantara multiple linier regression serta spatial autoregressive model. Variabel yang berpengaruh signifikan terhadap spatial error model tingkat pengangguran terbuka di Provinsi Jawa Timur adalah persentase penduduk miskin serta distrubusi PDRB atas dasar harga berlaku menurut lapangan usaha jasa lainnya.

\section{B. Saran}

Beberapa saran-saran yang dapat diberikan untuk penelitian yang akan dilakukan selanjutnya adalah,

1. Kabupaten Magetan, Kabupaten Madiun, Kota Kediri, Kabupaten Jombang, Kabupaten Sidoarjo, Kabupaten Pasuruan, Kabupaten Gresik, Kota Surabaya, Kota Malang dan Kota Pasuruan mendapatkan perhatian khusus sebab memiliki angka pengangguran terbuka tinggi.

2. Variabel independen sebaiknya yang memiliki korelasi tinggi terhadap tingkat pengangguran terbuka sehingga bisa menghasilkan kebaikan model yang lebih tinggi. Pemodelan regresi spasial menggunakan data panel supaya bisa mengetahui perubahan tingkat pengangguran terbuka setiap tahunnya.

\section{DAFTAR PUSTAKA}

[1] L. Anselin, Spatial Econometrics: Methods and Models, Springer Science + Business Media Dordrecht, 1988.

[2] "Badan Pusat Statistik," 2017. [Online]. Available: https://sirusa.bps.go.id/index.php?r=indikator/view\&id=44. [Accessed 6 February 2017].

[3] "Badan Pusat Statistik Provinsi Jawa Timur," 2017. [Online]. Available: https://jatim.bps.go.id/linkTableDinamis/view/id/11. [Accessed 6 March 2017].

[4] Mariana, "Pendekatan Regresi Spasial dalam Pemodelan Tingkat Pengangguran Terbuka," Sekolah Pascasarjana IPB, Bogor, 2012.

[5] Marsono, "Pemodelan Pengangguran Terbuka di Indonesia dengan Pendekatan Ekonometrika Spasial Data Panel," Program Magister Jurusan Statistika FMIPA ITS, Surabaya, 2013.

[6] R. Rahmawati, D. Safitri and O. U. Fairuzdhiya, "Analisis Spasial Pengaruh Tingkat Pengangguran terhadap Kemiskinan di Indonesia," 
Media Statistika Vol 8, pp. 23-30, 2015.

[7] B. Sumantri, "Analisis Regresi Terapan Edisi Kedua," in Applied Regression Analysis (Second Edition), Jakarta, PT Gramedia Pustaka Utama, 1992, p. 688.

[8] M. D. Ward and K. S. Gleditsch, Spatial Regression Model, California: Sage Publications, Inc, 2008.
[9] J. P. LeSage, The Theory and Practice of Spatial Econometrics, Asia Pacific Press, 1999.

10] D. N. Gujarati, Basic Econometric Fourth Edition, New York: The McGraw - Hill Companies, 2004. 